\section{Prevalence, risk factors and hepatitis B immunization: helping fill the gap on hepatitis B epidemiology among homeless people, Goiânia, Central Brazil}

\section{Prevalência, fatores de risco e imunização contra} a hepatite B: ajudando a preencher as lacunas na epidemiologia da hepatite $B$ entre pessoas em situação de rua em Goiânia, Goiás, Brasil

Prevalencia, factores de riesgo e inmunización contra la hepatitis B: ayudando a completar las lagunas en la epidemiología de la hepatitis B entre personas sin techo en Goiânia, Goiás, Brasil
Paulie Marcelly Ribeiro dos Santos Carvalho 1

Marcos André de Matos 1

Regina Maria Bringel Martins 2

Raquel Silva Pinheiro 1

Karlla Antonieta Amorim Caetano 1

Márcia Maria de Souza 1

Megmar Aparecida dos Santos Carneiro 2

Sheila Araujo Teles 1

doi: 10.1590/0102-311X00109216

\begin{abstract}
Data are limited in Brazil on hepatitis B infection among homeless individuals, a marginalized population with high risk of sexually transmissible infections (STI), including hepatitis B. The aim of this study was to investigate hepatitis B epidemiology in homeless persons lodged in a public shelter in Goiânia, Central Brazil. From August 2014 to June 2015, 353 individuals were interviewed and tested for markers of $H B V$ infection. Overall $H B V$ prevalence was 21.8\% (95\% CI: 17,82-26,41), and 19,5\% (95\% CI: 15,75-24,0) showed a serological profile of previous $H B V$ vaccination. Older individuals (> 50 years), blacks, and homosexuals or bisexuals showed increased exposure to $H B V$. The low frequency of individuals immunized against $H B V$, high social vulnerability, and risk behaviors emphasize the need for health services administrators to provide more opportunities for $H B V$ vaccination in this target population.
\end{abstract}

Hepatitis B; Immunization; Homeless Persons

\section{Correspondence}

S. A. Teles

Faculdade de Enfermagem, Universidade Federal de Goiás.

Rua 227, quadra 68, s/n, Setor Leste Unversitário, Goiania, GO 74605-080, Brasil.

sheila.fen@gmail.com

1 Faculdade de Enfermagem, Universidade Federal de Goiás, Goiannia, Brasil.

2 Instituto de Patologia Tropical e Saúde Pública, Universidade Federal de Goiás, Goiânia, Brasil. 


\section{Introduction}

Street population experiences prejudice and discrimination, and has a strong intersection with drug users and sex workers, representing a vulnerable population that mostly has poor access to health services ${ }^{1}$. Globally, the number of people living on the streets is estimated at 100 million. These people have death rates four times higher than the general population and a high prevalence of psychiatric disorders, abuse of licit and illicit drugs, and infectious diseases 2. In Brazil, about 50,000 people live on the streets in state capitals, the Federal District and cities with over 300,000 inhabitants 3.

It is estimated that 2 billion people have been infected with hepatitis B virus (HBV) worldwide, and that every year 600,000 people die due to the consequences of viral infection such as chronic hepatitis, cirrhosis, and hepatocellular carcinoma 4. In Brazil, where the overall prevalence of $\mathrm{HBV}$ is low, the burden of the infection is concentrated mainly in populations with social vulnerability and risk behaviors 5,6 .

Homeless people have been disproportionately affected by infectious diseases including HBV infection. In Brazil, the only study on hepatitis B in this population was carried out in the beginning of 2000 among 330 shelter users in the city of São Paulo, Southeastern Region of the country. The author showed $30.6 \%$ were previously exposed to HBV and 3.3\% were chronic HBsAg carriers 7 , suggesting a high prevalence of hepatitis B among this population.

Hepatitis B vaccine has been available for almost 20 years in our country 8 , and therefore it should be of great interest to decision-makers to know whether this policy has reached this target-population. Therefore the purpose of this study was to investigate the prevalence, risk factors and HBV immunization status among homeless people being served in a public shelter in the city of Goiânia, Central Brazil.

\section{Methodology}

This is a cross-sectional study carried out among homeless people served at a public shelter in the city of Goiânia (1,302,001 inhabitants). Data collection was conducted from August 2014 to June 2015. This shelter was opened in 2007, and has the capacity to serve approximately 240 individuals. This facility represented the only public shelter in the city during the period of investigation.

The Brazilian National Survey on Homelessness carried out in 2008 estimated the number of homeless people in Goiânia at 563 . The study sample was calculated on the basis of an alpha and beta error of $5 \%$ and $20 \%$, respectively, with an expected HBV prevalence of $30.6 \%{ }^{7}$ and a precision of $1.5 \%$. According to these data, the minimum sample size necessary was 311 individuals.

Those included in the study were individuals served by the public shelter, aged over 18 years. Subjects were excluded if they were under the effects of medication/psychoactive drugs at the time of the interview; and/or displayed behavior that would preclude the collection of a blood sample.

Data collection was conducted three days a week during the morning, afternoon, or evening. All individuals were interviewed in a private place, using a structured questionnaire containing questions about sociodemographic characteristics and predictors of HBV infection. 10mL of blood collected by venipuncture was subjected to detection of HBV markers: $\mathrm{HBsAg}$, total anti-HBc and anti-HBs (Bioelisa, Biokit S.A., Barcelona, Spain). Individuals whose sera were positive only for anti-HBs were considered vaccinated against HBV.

Data were analyzed using Stata SE, version 13 (StataCorp LP, College Station, USA). Prevalence was calculated with $95 \%$ confidence intervals (95\%CI). Descriptive analysis was conducted by frequency distribution, arithmetic mean and standard deviation. For analysis of potential predictors of exposure to HBV (HBsAg and/or total anti-HBc positive), individuals who had serological profile of previous vaccination against HBV were excluded. This study used the chi-square test $\left(\chi^{2}\right)$ or Fisher's exact test to assess differences between proportions. For calculation of the adjusted prevalence ratio $(\mathrm{PR})$, variables that presented a $\mathrm{p}$-value $<0.10$ were included in a Poisson regression model with robust error variance. P-values $<0.05$ were considered statistically significant.

This project was approved by the Ethics Committee of the Federal University of Goiás (protocol n. 045/13). Since individuals living on the streets have great geographical mobility and poor access for 
returning surveys, rapid testing was carried out for the detection of HBsAg markers (VIKIA - HBsAg, BioMérieux Brasil S/A, Rio de Janeiro, Brazil), following the recommendations of the Brazilian Ministry of Health. Individuals HBsAg positive were referred to the public health service, per prior agreements with the Municipal Health Secretariat of Goiânia, for evaluation and treatment (if necessary).

\section{Results}

A total of 353 eligible individuals participated in the study. Of them, $81.3 \%$ were male, and $20.4 \%$ were married. The median age of study participants was 36 years, ranging between 18 and 86 years. Eighty-nine (25.2\%) individuals reported less than five years of education, 188 (53.3\%) 5-9 years, and 76 (21.5\%) more than nine years. Two hundred and fifteen (61\%) individuals self-declared mixed race, 62 (17.6\%) white, 58 (16.4\%) black, and 18 (5\%) other race/ethnicity. Most (57.5\%) of the participants had experienced sleeping on the street.

Some serological markers for HBV infection were found in 77 participants, resulting in an overall prevalence of $21.8 \%$ (95\%CI: 17.8-26.4). Two participants (0.6; 95\%CI: $0.15-2.04)$ were HBsAg and total anti-HBc positive, 14 (4.53; 95\%CI: 2.80-7.23) were positive for only anti-HBc and 61 (17.28; 95\%CI: $13.69-21.57$ ) for anti-HBs and anti-HBc. Isolated anti-HBs positivity was detected in $19.5 \%$ (95\%CI: 15.7-24.0) of participants (Table 1).

It was found that the prevalence of HBV exposure (anti-HBc) increased from $10.8 \%$ in subjects aged 18 -30 years to $46.8 \%$ in individuals older than 50 years. The prevalence of immunized (anti-HBs isolated) participants dropped from $53.6 \%$ in subjects aged $18-30$ years to $1.4 \%$ in individuals older than 50 years $(\mathrm{p}<0.001)$. There is no difference between the proportions of vaccinated vs. unvaccinated homeless regarding sex, ethnicity, and years of education $(\mathrm{p}>0.05)$.

Statistically significant differences were observed in the proportion of individuals exposed to HBV, considering the following variables: age, sleeping on the street, and sexual intercourse with people living with HIV/AIDS ( $\mathrm{p}<0.05)$. Also, the variables ethnicity (self-identified), sexual orientation, and history of sexual violence tended to be associated $(\mathrm{p}<0.10)$ (Table 2).

These variables, as well as sex, were included in a Poisson regression model with robust error variance, and age > 50 years (adjusted PR: 3.06), black (adjusted PR: 1.81), and homosexuality or bisexuality (adjusted PR: 2.60 and 1.80, respectively) were independently associated with exposure to HBV (Table 3).

\section{Discussion}

Corroborating findings observed by other investigators in countries of low to intermediate endemicity 10,11,12,13, a high prevalence of HBV markers (21.8\%; 95\%CI: 17.8-26.4) was observed among homeless people in Goiânia. This was higher than that estimated for the adult population of capitals in the same region of the country $(13.2 \%$; $95 \%$ CI: $10.9 \%-15.5 \%) 14$, and also for those found in other

\section{Table 1}

Prevalence of hepatitis B virus (HBV) markers among 353 homeless individuals in Goiânia, Central Brazil.

\begin{tabular}{|c|c|c|c|}
\hline HBV marker & $\mathbf{n}$ & $\%$ & $95 \% \mathrm{Cl}$ \\
\hline Anti-HBc/HBsAg & 2 & 0.57 & $0.15-2.04$ \\
\hline Anti-HBc/Anti-HBs & 61 & 17.28 & $13.69-21.57$ \\
\hline Anti-HBc only & 14 & 4.53 & $2.80-7.23$ \\
\hline Any exposure marker & 77 & 21.81 & $17.82-26.41$ \\
\hline Anti-HBs only & 69 & 19.55 & $15.75-24.00$ \\
\hline
\end{tabular}

95\%Cl: 95\% confidence interval. 
Table 2

Bivariate analysis of risk factors associated with exposure to hepatitis B virus (HBV) among 353 homeless individuals in Goiânia, Central Brazil.

\begin{tabular}{|c|c|c|c|c|}
\hline \multirow[t]{2}{*}{ Variables } & \multicolumn{2}{|c|}{ HBV } & \multirow[t]{2}{*}{$\chi^{2}$} & \multirow[t]{2}{*}{ p-value } \\
\hline & $\begin{array}{c}\text { Positive }(n=77) \\
n(\%)\end{array}$ & $\begin{array}{c}\text { Negative }(n=207) \\
n(\%)\end{array}$ & & \\
\hline \multicolumn{5}{|l|}{ Age (years) } \\
\hline $18-30$ & $11(16.9)$ & $54(83.1)$ & 19.24 & $<0.001$ \\
\hline $31-40$ & $20(19.8)$ & $81(80.2)$ & & \\
\hline $41-50$ & $17(29.8)$ & $40(70.2)$ & & \\
\hline$>50$ & $29(47.5)$ & $32(52.5)$ & & \\
\hline \multicolumn{5}{|l|}{ Sex } \\
\hline Male & $65(27.8)$ & $169(72.2)$ & 0.298 & 0.585 \\
\hline Female & $12(24.0)$ & $38(76.0)$ & & \\
\hline \multicolumn{5}{|l|}{ Black } \\
\hline No & $60(25.1)$ & $179(74.9)$ & & \\
\hline Yes & $17(37.8)$ & $28(62.2)$ & 3.078 & 0.079 \\
\hline \multicolumn{5}{|l|}{ Education (years) } \\
\hline$>9$ & $14(21.5)$ & $51(78.5)$ & & \\
\hline $5-9$ & $38(27.1)$ & $102(72.9)$ & 1.843 & 0.398 \\
\hline$\leq 4$ & $25(31.6)$ & $54(68.4)$ & & \\
\hline \multicolumn{5}{|c|}{ Sleeping on the street } \\
\hline No & $38(32.2)$ & $80(67.8)$ & & \\
\hline Yes & $39(23.5)$ & $127(76.5)$ & 2.647 & 0.104 \\
\hline \multicolumn{5}{|c|}{ Sexual orientation } \\
\hline Heterosexual & $66(25.3)$ & $195(74.7)$ & & \\
\hline Homosexual & $6(46.2)$ & $7(53.8)$ & 5.476 & 0.065 \\
\hline Bisexual & $5(50.0)$ & $5(50.0)$ & & \\
\hline \multicolumn{5}{|c|}{ Previous sexual violence * } \\
\hline No & $55(24.8)$ & $167(75.2)$ & & \\
\hline Yes & $22(36.1)$ & 39 (63.9) & 3.080 & 0.079 \\
\hline \multicolumn{5}{|c|}{ Number of partners } \\
\hline$\leq 10$ & $29(30.2)$ & $67(69.8)$ & & \\
\hline $11-20$ & $10(22.2)$ & $35(77.8)$ & & \\
\hline $21-30$ & $5(22.7)$ & $17(77.3)$ & 1.226 & 0.747 \\
\hline$>30$ & $33(27.3)$ & $88(72.7)$ & & \\
\hline \multicolumn{5}{|c|}{ Condom use with steady partner $(n=110)$ * } \\
\hline Always & $6(33.3)$ & $12(66.7)$ & & \\
\hline Sometimes & $9(23.1)$ & $30(76.9)$ & 0.667 & 0.716 \\
\hline Never & $14(26.4)$ & $36(73.6)$ & & \\
\hline \multicolumn{5}{|c|}{ Condom use with occasional partner $(n=152)$} \\
\hline Always & $17(25.4)$ & $50(74.6)$ & & \\
\hline Sometimes & $13(26.5)$ & $36(73.5)$ & 2.149 & 0.342 \\
\hline Never & $8(42.1)$ & $11(57.9)$ & & \\
\hline \multicolumn{5}{|c|}{ Sex in exchange for money or drugs * } \\
\hline No & $70(27.7)$ & $183(72.3)$ & 0.163 & 0.686 \\
\hline Yes & $7(24.1)$ & $22(75.9)$ & & \\
\hline \multicolumn{5}{|c|}{ Sex with partner living with HIV/AIDS $(n=284)$ * } \\
\hline No & $52(25.5)$ & $152(74.5)$ & 4.187 & 0.041 \\
\hline Yes & $9(47.4)$ & $10(52.6)$ & & \\
\hline \multicolumn{5}{|c|}{ Sex with drug users $(n=284)$ * } \\
\hline No & $36(30.8)$ & $81(69.2)$ & 1.390 & 0.238 \\
\hline Yes & $38(24.4)$ & $118(75.6)$ & & \\
\hline
\end{tabular}

(continues) 
Table 2 (continued)

\begin{tabular}{|c|c|c|c|c|}
\hline \multirow[t]{2}{*}{ Variables } & \multicolumn{2}{|c|}{ HBV } & \multirow[t]{2}{*}{$\chi^{2}$} & \multirow[t]{2}{*}{ p-value } \\
\hline & $\begin{array}{c}\text { Positive }(n=77 \\
n(\%)\end{array}$ & $\begin{array}{c}\text { Negative }(n=207 \\
\text { n (\%) }\end{array}$ & & \\
\hline \multicolumn{5}{|c|}{ Anal sex $(n=284)$ * } \\
\hline No & $34(24.5)$ & $105(75.5)$ & 0.863 & 0.353 \\
\hline Yes & $42(29.4)$ & $101(70.6)$ & & \\
\hline \multicolumn{5}{|c|}{ Illicit drug use (previous six months) } \\
\hline No & $32(32.0)$ & $68(68.0)$ & 1.866 & 0.172 \\
\hline Yes & $45(24.5)$ & $139(75.5)$ & & \\
\hline \multicolumn{5}{|c|}{ Sharing of objects for personal use } \\
\hline No & $23(25.3)$ & $68(74.7)$ & 0.229 & 0.632 \\
\hline Yes & $54(28.0)$ & $139(72.0)$ & & \\
\hline \multicolumn{5}{|c|}{ Tattoos/Piercings } \\
\hline No & $46(27.4)$ & $122(72.6)$ & 0.015 & 0.903 \\
\hline Yes & $31(26.7)$ & $85(73.3)$ & & \\
\hline \multicolumn{5}{|c|}{ Previously incarcerated * } \\
\hline No & $36(27.3)$ & $96(72.7)$ & 0.013 & 0.909 \\
\hline Yes & $40(26.7)$ & $110(73.3)$ & & \\
\hline \multicolumn{5}{|c|}{ Previous STI * } \\
\hline No & $42(24.7)$ & $128(75.3)$ & 1.154 & 0.283 \\
\hline Yes & $31(30.7)$ & $70(69.3)$ & & \\
\hline \multicolumn{5}{|c|}{ History of hepatitis in family } \\
\hline No & $62(25.8)$ & $178(74.2)$ & & \\
\hline Yes & $15(34.1)$ & $29(65.9)$ & 1.283 & 0.257 \\
\hline \multicolumn{5}{|c|}{ Previous blood transfusion * } \\
\hline No & $59(25.2)$ & $175(74.8)$ & & \\
\hline Yes & $14(32.6)$ & 29 (67.4) & 1.010 & 0.315 \\
\hline
\end{tabular}

STI: sexually transmitted infection.

* No information: previous sexual violence $=1$; condom use with steady partner = 174; condom use with occasional partner = 149; sex in exchange for money or drugs = 2; sex with partner living with HIV/AIDS = 61; sex with drug users = 11; anal sex = 2; previously incarcerated = 2; previous STI = 13; previous blood transfusion $=7$.

\section{Table 3}

Multivariate analysis of variables associated with hepatitis B markers.

\begin{tabular}{lcc}
\hline Variable & Adjusted PR (95\%Cl) & p-value \\
\hline Age (years) & 1.00 & \\
$18-30$ & $1.14(0.60-2.20)$ & 0.685 \\
$31-40$ & $1.59(0.82-3.08)$ & 0.168 \\
$41-50$ & $3.06(1.71-5.47)$ & 0.000 \\
$>50$ & $1.81(1.17-2.79)$ & 0.007 \\
Black & $0.76(0.53-1.10)$ & 0.137 \\
Sleeping on the street & & \\
Sexual orientation & 1.00 & 0.008 \\
Heterosexual & $2.60(1.28-5.28)$ & 0.030 \\
Homosexual & $1.80(1.06-3.08)$ & 0.806 \\
Bisexual & $1.00(0.99-1.00)$ & 0.407 \\
Sex with partner living with HIV/AIDS & $0.99(0.96-1.01)$ & \\
Previous sexual violence & & \\
\hline
\end{tabular}

95\%Cl: 95\% confidence interval; PR: prevalence ratio. 
vulnerable populations from the same region who have a large intersection with homeless such as recyclable waste collectors $(\mathrm{n}=431 ; 12.8 \%$; 95\%CI: 9.8-16.2) 15 and users of illicit drugs $(\mathrm{n}=852 ; 14 \%$; 95\%CI: 11.7-16.5) 16. However, the prevalence found among homeless people in Goiânia was lower than that found ten years before by Brito et al. 7 (30.6\%; 95\%CI: 25.9-35.8) in São Paulo. In Goiânia, the participants were younger and had better education levels. These characteristics very likely contributed to these findings.

The gold standard for assessment of vaccine coverage is the immunization record (a card issued by the public health system). However, in adult populations there is little chance of access to this information, especially if the population has little access to public health services such as those people living on the streets 1 . Furthermore, the verbal report of previous hepatitis B vaccination is poorly reliable 17,18. Therefore, despite methodological limitations, detection of anti-HBs in serum alone is used as indicator prior immunization.

In our study, only $19.5 \%$ of participants presented a serological profile of prior immunization, confirming the low frequency of hepatitis B vaccination among vulnerable populations in our region and elsewhere 16,19,20,21. However, it should be noted the wide variation observed in the distribution by age group, with prevalence of $53.6 \%$ in individuals aged 18 to 30 years dropping to $1.4 \%$ among those aged above 50 years. These better results among younger subjects very likely reflects the outcome of the Brazilian National Immunization Program policy, which from the 2000s effectively implemented hepatitis B vaccination in children and adolescents nationwide. This policy was also gradually extended to older people and vulnerable populations, and is currently available to older people 22 . These findings and that of higher HBV prevalence among older homeless reinforce the need of health managers to invest in more persuasive strategies to vaccinate these specific populations, particularly older subjects.

We found that self-reported homosexual or bisexual orientation was statistically associated with HBV exposure $(\mathrm{p}=0.009$ and $\mathrm{p}=0.030)$, corroborating previous studies that have shown a higher risk of hepatitis B among men who have sex with men (MSM) 23,24. Many MSM have multiple sexual partners and use condoms inconsistently during sexual intercourse, behaviors that put them at increased risk for sexually transmitted infections, including hepatitis B 23,25.

In our country, social racial categorization depends on appearance of the individual, being classified as white, black, mixed race, indigenous and yellow ${ }^{26}$. According to the 2010 demographic census 2010, the Brazilian population is $47.7 \%$ white, $43.1 \%$ mixed race, and $7.6 \%$ black 27 . This composition is dramatically different from that found among the homeless studied here, with $78.6 \%$ self-declared mixed race or black. In addition, in our country and elsewhere 28,29,30, the black population is subject to greater economic and social vulnerability, which can contribute to disproportionate susceptibility to infectious diseases. Our findings reinforce these assumptions, since ethnicity was predictive of HBV infection (adjusted PR: 1.70; $\mathrm{p}=0.024$ ).

Some limitations of the study should be presented. The study was conducted in a public institution that houses people on the streets and may not be representative of the entire homeless population in the city. However, the characteristics of the individuals studied were similar to those in the Brazilian National Survey on Homelessness ${ }^{3}$, giving the findings external validity. The prevalence data for vaccination coverage may be underestimated, since the date of the last dose of vaccine is unknown, and according to the kinetics of this marker, the titers of anti-HBs decline over the years. However, our results are consistent with other studies in vulnerable populations. Finally, many questions are morally sensitive, and despite the team's efforts to assure the respondent of privacy and anonymity, some answers may not have been truthful.

Although the study has been limited to individuals housed in a shelter, it is believed that the obtained data will contribute to the body of knowledge on the homeless population, and encourage more specific health policies for this population, which in most cases is outside the public health services and presents social and individual vulnerabilities that put them at risk of infections such as hepatitis B. 


\section{Contributors}

P. M. R. S. Carvalho contributed to the data acquisition and drafted the article. M. A. Matos contributed to the conception and design and revised the paper. R. M. B. Martins revised the paper. R. S. Pinheiro, K. A. A. Caetano, M. M. Souza, and M. A. S. Carneiro contributed to the data acquisition and revised the paper. S. A. Teles contributed to the data analysis and interpretation and revised the paper.

\section{Acknowledgments}

We thank the staff and the users of the shelter. We also thank Brian Rean for English language review. United Nations Office on Drugs and Crime (UNODC) and the Brazilian Ministry of Health (Coordination of STI/HIV/AIDS and Viral Hepatitis) for the financial support.

\section{References}

1. Fazel S, Geddes JR, Kushel M. The health of homeless people in high-income countries: descriptive epidemiology, health consequences, and clinical and policy recommendations. Lancet 2014; 384:1529-40.

2. Beijer U, Wolf A, Fazel S. Prevalence of tuberculosis, hepatitis $\mathrm{C}$ virus, and HIV in homeless people: a systematic review and meta-analysis. Lancet Infect Dis 2012; 12:859-70.

3. Ministério do Desenvolvimento Social e Combate à Fome. Política nacional para inclusão social da população em situação de rua. Brasília: Ministério do Desenvolvimento Social e Combate à Fome; 2008.

4. World Health Organization. Prevention \& control of viral hepatitis infection: framework for global action. Geneva: World Health Organization; 2012.

5. Schuelter-Trevisol F, Custódio G, Silva AC, Oliveira MB, Wolfart A, Trevisol DJ. HIV, hepatitis B and C, and syphilis prevalence and coinfection among sex workers in Southern Brazil. Rev Soc Bras Med Trop 2013; 46:493-7.

6. Souto FJ. Distribution of hepatitis B infection in Brazil: the epidemiological situation at the beginning of the 21 st century. Rev Soc Bras Med Trop 2016; 49:11-23.

7. Brito VO, Parra D, Facchini R, Buchalla CM. Infecção pelo HIV, hepatites B e C e sífilis em moradores de rua, São Paulo. Rev Saúde Pública 2007; 41 Suppl 2:47-56.

8. Coordenação Geral do Programa Nacional de Imunizações, Departamento de Vigilância Epidemiológica, Secretaria de Vigilância em Saúde, Ministério da Saúde. Programa nacional de imunizações (PNI): 40 anos. Brasília: Ministério da Saúde; 2013.

9. Coordenação-Geral dos Direitos da População em Situação de Rua, Secretaria de Direitos Humanos. Política Nacional para a População em Situação de Rua. http://repositorio. enap.gov.br/bitstream/handle/1/763/8-\%20 Popula\%C3\%A7\%C3\%A3o\%20em\%20Situa\% C3\%A7\%C3\%A3o\%20de\%20Rua-Carlos\%20 Ricardo\%20-\%202.pdf?sequence $=9$ (accessed on 18/Aug/2016).

10. Stein JA, Andersen RM, Robertson M, Gelberg L. Impact of hepatitis B and C infection on health services utilization in homeless adults: a test of the Gelberg-Andersen behavioral model for vulnerable populations. Health Psychol 2012; 3:20-30.

11. Leiva-Hidalgo J, Madrigal-Méndez A, SalasSegura D. Seroprevalencia de hepatitis B, C y VIH en indigentes en Costa Rica. Rev Costarric Salud Pública 2013; 22:113-8.

12. Poulos R, Ferson M, Orr K, Lucy A, Botham S, McCarthy M, et al. Risk factors and seroprevalence of markers for hepatitis A, B and C in persons subject to homelessness in inner Sydney. Aust N Z J Public Health 2007; 31:247-51. 
13. Vahdani P, Hosseini-Moghaddam SM, Family A, Moheb-Dezfouli R. Prevalence of HBV, $\mathrm{HCV}, \mathrm{HIV}$, and syphilis among homeless subjects older than fifteen years in Tehran. Arch Iranian Med 2009; 12:483-7.

14. Pereira LM, Martelli CM, Merchán-Hamann E, Montarroyos UR, Braga MC, de Lima ML, et al. Population-based multicentric survey of hepatitis B infection and risk factor differences among three regions in Brazil. Am J Trop Med Hyg 2009; 81:240-7.

15. Marinho TA, Lopes CL, Teles SA, Matos MA, Matos MA, Kozlowski AG, et al. Epidemiology of hepatitis $B$ virus infection among recyclable waste collectors in central Brazil. Rev Soc Bras Med Trop 2014; 47:18-23.

16. Ferreira RC, Rodrigues FP, Teles SA, Lopes CL, Motta-Castro AR, Novais AC, et al. Prevalence of hepatitis $B$ virus and risk factors in Brazilian non-injecting drug users. J Med Virol 2009; 81:602-9.

17. Loulergue P, Pulcini C, Massin S, Bernhard M, Fonteneau L, Levy-Brühl D, et al. Validity of self-reported vaccination status among French healthcare students. Clin Microbiol Infect 2014; 20:O1152-4.

18. Topp L, Day C, Dore GJ, Maher L. Poor criterion validity of self-reported hepatitis $\mathrm{B}$ infection and vaccination status among injecting drug users: a review. Drug Alcohol Rev 2009; 28:669-75.

19. Carneiro LM, Mousquer GJ, Pinheiro RS, Castro AR, Franca DD, Caetano KA, et al. Outreach hepatitis $B$ vaccination of female sex workers in Central-West Brazil: immunization status, compliance, and immune response. J Public Health Manag Pract 2014; 20:662-6.

20. Lu PJ, Byrd KK, Murphy TV, Weinbaum C. Hepatitis B vaccination coverage among highrisk adults 18-49 years, U.S., 2009. Vaccine 2011; 29:7049-57.

21. da Silva LN, da Silva França DD, Del-Rio NHA, Dos Santos Carneiro MA, Martins $\mathrm{RMB}$, Guimarães RA, et al. Low prevalence, low immunization and low adherence to full hepatitis $B$ vaccine scheme and high-risk behaviors among crack cocaine users in Central Brazil. J Infect Public Health 2017; 10:76-83.
22. Coordenação Geral do Programa Nacional de Imunizações, Departamento de Vigilância das Doenças Transmissíveis, Secretaria de Vigilância em Saúde, Ministério da Saúde. Nota técnica conjunta no 02/2013/CGPNI/DEVEP E CGDHRV/DST-AIDS/SVS/MS. Ampliação da oferta da vacina hepatite B para a faixa etária de 30 a 49 anos em 2013. Brasília: Ministério da Saúde; 2013.

23. Li D, Jia Y, Ruan Y, Liu Y, Li Q, Liang H, et al. Correlates of incident infections for HIV, syphilis, and hepatitis B virus in a cohort of men who have sex with men in Beijing. AIDS Patient Care STDS 2010; 24:595-602.

24. Wang C, Wang Y, Huang X, Li X, Zhang T, Song $M$, et al. Prevalence and factors associated with hepatitis B immunization and infection among men who have sex with men in Beijing, China. PLoS One 2012; 7:e48219.

25. Nyamathi A, Salem B, Reback CJ, Shoptaw S, Branson CM, Idemundia FE, et al. Correlates of hepatitis B virus and HIV knowledge among gay and bisexual homeless young adults in Hollywood. Am J Mens Health 2013; 7:18-26.

26. Osorio RG. Sistema classificatório de "cor ou raça” do IBGE. Brasília: Instituto de Pesquisa Econômica Aplicada; 2003. (Texto para Discussão, 996).

27. Instituto Brasileiro de Geografia e Estatística. Características da população e dos domicílios resultados do universo. Censo demográfico, 2010. Rio de Janeiro: Instituto Brasileiro de Geografia e Estatística; 2011.

28. Perreira KM, Telles EE. The color of health: skin color, ethnoracial classification, and discrimination in the health of Latin Americans. Soc Sci Med 2014; 116:241-50.

29. Chehuen Neto JA, Fonseca GM, Brum IV, Santos JLCT, Rodrigues TCGF, Paulino KR, et al. Política Nacional de Saúde Integral da População Negra: implementação, conhecimento e aspectos socioeconômicos sob a perspectiva desse segmento populacional. Ciênc Saúde Coletiva 2015; 20:1909-16.

30. Gee GC, Ford CL. Structural racism and health inequities: old issues, new directions. Du Bois Rev 2011; 8:115-32. 


\section{Resumo}

No Brasil, existem poucos dados sobre a infecção por hepatite $B$ entre pessoas em situação de rua, uma população marginalizada com alto risco para infecções sexualmente transmissiveis (IST), incluindo a hepatite B. O objetivo deste estudo foi investigar a epidemiologia da hepatite $B$ em pessoas alojadas em um abrigo público da cidade de Goiânia, Brasil Central. De agosto de 2014 a junho de 2015, 353 indivíduos foram entrevistados e testados para os marcadores da infecção pelo $\mathrm{HBV}$. Uma prevalência global de 21,8\% (IC95\%: 17,8226,41) para HBV foi estimado, e 19,5\% (IC95\%: 15,75-24,0) apresentaram perfil sorológico de vacinação prévia contra o HBV. Ser mais velho (acima de 50 anos de idade), preto e homossexual ou bissexual foram preditores de exposição ao $\mathrm{HBV}$. A baixa frequência de indivíduos imunizados contra o HBV, bem como de alta vulnerabilidade social e ocorrência de comportamentos de risco reforçam a necessidade dos gestores de saúde proporcionar mais oportunidades de vacinação para esta população-alvo.

Hepatite B; Imunização; Pessoas em Situação de Rua

\section{Resumen}

En Brasil, existen pocos datos sobre la infección por hepatitis $B$ entre personas sin techo, una población marginalizada con un alto riesgo de infecciones sexualmente transmisibles (IST), incluyendo la hepatitis B. El objetivo de este estudio fue investigar la epidemiología de la hepatitis B en personas alojadas en un albergue público de la ciudad de Goiânia, Brasil Central. De agosto de 2014 a junio de 2015, se entrevistó a 353 individuos y se probaron los marcadores de la infección por $\mathrm{HBV}$. Se estimó una prevalencia global de un 21,8\% (IC95\%: 17,82-26,41) para HBV, y 19,5\% (IC95\%: 15,75-24,0) presentaron un perfil serológico de vacunación previa contra el HBV. Ser más viejo (por encima de 50 años de edad), negro y homosexual o bisexual fueron predictores de exposición al $\mathrm{HBV}$. La baja frecuencia de individuos inmunizados contra el $H B V$, así como la alta vulnerabilidad social y ocurrencia de comportamientos de riesgo refuerzan la necesidad de los gestores de salud de proporcionar más oportunidades de vacunación para esta población-objetivo.

Hepatitis B; Inmunización; Personas sin Hogar
Submitted on 23/Jun/2016

Final version resubmitted on $01 / \mathrm{Sep} / 2016$

Approved on 22/Sep/2016 